Didáctica. Lengua y literatura

ISSN: 1130-0531

http://dx.doi.org/10.5209/DIDA.61955

\title{
Learning a Second Language in Pre-School: Using Dramatized Stories as a Teaching Resource
}

\author{
Yvette Coyle ${ }^{1}$; Pedro Antonio Férez Mora ${ }^{2}$
}

Recibido: 24 de septiembre de 2017 / Aceptado: 19 de junio de 2018

\begin{abstract}
In recent years, the interest in early language learning shown by both parents and politicians has led to the introduction of a second language (L2), particularly English, to children as young as two or three years old in pre-schools and kindergartens across Europe and beyond. The demands involved in teaching this age-range require from teachers a set of specialized skills to ensure that children's first experience with a new language is as enjoyable and fruitful as possible. This article discusses the impact of learner-internal and contextual factors on children's second language learning, together with the contribution that children make to the process in terms of their language-learning abilities. In doing so, key issues such as promoting comprehension, lexical acquisition and initial language production in the second language are addressed, together with the methodological implications derived from this knowledge. Finally, an age-appropriate approach for teaching children using predictable dramatized stories is presented.
\end{abstract}

Keywords: Pre-school education; second language learning; dramatized stories.

\section{[es] El aprendizaje de la segunda lengua en educación infantil: Los cuentos dramatizados como recurso didáctico}

Resumen. Recientemente, el interés general mostrado tanto por los padres como por los políticos en el aprendizaje temprano de idiomas ha culminado en la introducción de la enseñanza-aprendizaje de una segunda lengua, especialmente el inglés, en la educación infantil en Europa y otros países. Las demandas implicadas en enseñar una segunda lengua (L2) a niños de corta edad requieren del profesorado una serie de habilidades especializadas que puedan garantizar que el primer contacto del niño con un idioma diferente al de su lengua materna sea lo más divertido y provechoso posible. En este artículo analizamos el impacto de factores internos y externos en el aprendizaje temprano de la segunda lengua, junto con las aportaciones de los propios niños al proceso. Como consecuencia, examinaremos temas claves como la comprensión y producción inicial de la L2 y la adquisición del léxico, así como las implicaciones metodológicas derivadas de ellos. Finalmente, proponemos un enfoque didáctico para el aula de infantil basado en el uso de cuentos dramatizados para los primeros usos de la L2.

Palabras clave: Educación infantil; aprendizaje de segundas lenguas; cuentos dramatizados.

\footnotetext{
$1 \quad$ Dpto. de Didáctica de la Lengua y de la Literatura. Facultad de Educación. Universidad de Murcia (España) E-mail:ycoyle@um.es

2 Dpto. de Didáctica de la Lengua y de la Literatura. Facultad de Educación. Universidad de Murcia (España) E-mail:paferez@um.es
} 


\title{
[fr] Apprendre la langue e dans l'enseignement préscolaire: Les contes théâtralisés comme ressource didactique
}

\begin{abstract}
Résumé. Récemment, l'intérêt général montré tant par les pères comme par les politiciens dans l'apprentissage précoce de langues a terminé avec l'introduction de enseignement d'une seconde langue, spécialement l'Anglais, dans l'éducation infantile en Europe et d'autres pays. Les demandes impliquées en enseigner une seconde langue (L2) à des enfants requièrent du professorat une série d'habilités spécialisées qui peuvent garantir que le premier contact de l'enfant avec une langue différente à celui de sa langue maternelle est le plus amusant et utile possible. Dans cet article nous analysons l'impact de facteurs internes et externes dans l'apprentissage précoce de la seconde langue et les contributions des enfants au processus. Par conséquent, nous examinerons la compréhension et la production initiale de la L2 et l'acquisition du lexique, ainsi que les implications méthodologiques en dérivées. Finalement, une approche didactique avec des contes théâtralisés prévisibles est présentée.
\end{abstract}

Mots-clés: Éducation infantile; apprentissage de secondes langues; contes théâtralisés.

Sumario. 1. Factors influencing early second language learning. 2. Pre-school children as second language learners: Strategies for teachers. 2.1. Teaching with Total Physical Response. 2.2 Developing comprehension through simplified language use and familiar routines. 2.3. Developing lexical knowledge incidentally through recurrent exposure to L2 words. 2.4. Helping children to use the second language for simple communication. 3. Teaching the L2 with Dramatized Stories. 4. Conclusions. 5. Bibliographical references.

Cómo citar: Coyle, Y.; Férez Mora, P. A. (2018) Learning a second language in pre-school: Using dramatized stories as a teaching resource, Didáctica. Lengua y Literatura 30, 73-85.

\section{Factors influencing early second language learning}

Interest in early language learning has traditionally been based on the assumption that children can learn second languages more easily than older learners. The presumed advantage of younger learners in acquiring a more native-like accent in the L2 and better control over grammar was originally accredited to the existence of a Critical Period for language learning which was linked to the increased plasticity of the brain before the onset of puberty, after which it was considered impossible for older language learners to fully master the L2 system (Lenneberg, 1967). However, most research that has compared younger and older learners has provided evidence to refute the notion of a critical period, and it is now generally agreed that in formal instructional settings at least, (rather than naturalistic ones where the L2 is spoken in the wider community), older learners can outperform younger children on a number of measures including phonology, oral fluency, lexical acquisition or morphology (Muñoz, 2006). Collectively considered, results of research into age-related differences have coincided in highlighting that successful second language learning does not depend so much on the age of the learner, but on a combination of social, psychological and pedagogical factors, including the time and intensity of exposure to the second language (Curtain, 2003), the teacher's second language competence (Marinova Todd, Marshall \& Snow, 2000; Bowers and Vasilyeva, 2011) and the classroom activity children engage in (Rixon, 2013). What really counts then, is what children get to hear and do in the second language, how they do it and how often. 
It is a commonly held belief that teaching a second language to very young children is a simple task, since their linguistic needs can be easily fulfilled by learning colours, numbers, a few simple songs and some basic vocabulary in the L2. This type of misinformed opinion is a simplification of the complex reality involved in teaching children successfully. In fact, teachers of pre-school children face the challenging task of sustaining children's instinctive motivation for language learning while simultaneously fostering their developing cognitive and linguistic skills. Knowing how to do so is crucial in the different contexts in which children are exposed to a second language from an early age. These include bilingual playschools or day care centres, where the L2 is used a medium of communication throughout the day, as well as formal school settings where it is timetabled as a curricular subject for brief periods of between one and three hours a week.

These diverse models of early language learning differ with regard to the amount and intensity of contact time children experience with the L2, and often as regards the levels of second language competence held by the teachers who work there. Both factors have been found to influence children's L2 development. Research carried out in bilingual kindergartens in Germany has shown that the quality and quantity of L2 input that children receive has a significant effect on their comprehension of L2 lexis and grammar (Weitz, Pahl, Flymann Mattsson, Buyl \& Kalbe, 2010). Similarly, studies in school settings in the Netherlands have provided evidence to suggest that less than 60 minutes of instructional time per week has a negligible impact on young learners' vocabulary acquisition (Unsworth, Persson, Prins \& De Bot, 2015). This research raises important questions about the organization of different forms of early language learning and the role of teachers in the process. In some educational contexts (e.g. Spain, China, South Korea) English is taught by non-native English speaking teachers (NNEST), many of whom have been trained to teach older children and are largely unfamiliar with the routines and characteristics of preschool classrooms. However, these specialist teachers frequently have higher levels of linguistic competence than homeroom teachers, whose proficiency in English is lower, but who are skilled in working with pre-schoolers. In less formal kindergarten settings, especially in the private sector, native English-speaking teachers (NEST) are frequently employed for commercial purposes. Yet the issue of teachers' linguistic competence has only recently been the subject of investigation. Research into the impact of Dutch English as a foreign language (EFL) teachers' oral proficiency levels on the language skills of 4-year-old learners found that groups taught by NNEST at intermediate levels of proficiency (B on the Common European Framework of Reference), scored significantly lower on vocabulary and grammatical measures than children taught by i) NESTs, ii) NNESTs co-teaching with NESTs and iii) NNESTS with higher levels of competence (Unsworth et al, 2015). Similarly, Weitz et al (2010) reported that the quality of input provided by teachers in different bilingual kindergartens in Germany, in terms of its lexical and structural richness, had a greater impact on the receptive grammatical L2 knowledge of 3-to-6 year olds than the amount of L2 input alone.

On the basis of this evidence, it would seem reasonable to argue that teachers of very young learners should be fully competent in the L2 in order to provide high quality input to children at the initial stages of second language learning. If teachers of young learners struggle to express themselves in the L2, or restrict the quality of input the learners receive to a few recurrent words and formulaic language, then 
this is all that children are likely to learn. Yet as Cameron (2003) has pointed out, children are capable of doing much more than we think and it is vital that teachers maximize this enormous potential for learning. Teachers of pre-school children need to be aware of how to use the second language effectively to create a stimulating and linguistically rich learning environment and require the linguistic and methodological competence necessary to do so. This involves understanding the skills, needs and interests children bring to second language learning. It also requires the expertise to design and implement suitable age-appropriate activities, which both challenge and motivate children in their initial contact with the L2.

Insights from theories of learning and child development help us understand how children make sense of the world and usefully inform the practice of second language teaching in young learner classrooms. Sociocultural learning theory, as evidenced in the work of Vygotsky and Bruner, emphasizes the social nature of learning and the role of interaction in children's cognitive development. Vygotskian theory suggests that children's learning is mediated primarily through dialogic interaction with adults or more experienced peers. External manifestations of language are then internalized to structure thought processes and promote concept formation. In his work on first language acquisition, Bruner (1985) described how children acquire their mother tongue by routinely participating with parents and carers in highly structured interactive activities (getting dressed, mealtimes, reading stories) in which the adult supports and encourages the child's initial use of language. During these communicative situations, the child's progressive incorporation into contextualized language use is scaffolded by the adult in an asymmetrical process involving contingent and reciprocal interaction, until the child eventually begins to communicate independently.

In applying these premises to early L2 learning, enormous importance is placed on the teacher's use of language and on the careful sequencing of learning tasks to promote children's linguistic and cognitive development. Teachers need to be aware of the importance of setting up predictable, interactive exchanges as part of their regular teaching activity, in order to encourage children's active use of the second language. These exchanges might include the type of routines found in bilingual kindergartens (e.g. checking attendance, giving out snacks at break time, taking naps) or the use of specially planned dramatized narratives known as 'formats' (Artigal, 2003) (see below). As children make progress in the L2, classroom activities need to become increasingly demanding to enable learners develop their ability to understand and express meanings in the second language.

\section{Pre-school children as second language learners: implications for teachers}

When children begin learning a second language from the age of 2 or 3 onwards they bring to the learning process a combination of characteristics and developing skills that help them in their initial contact with the new language. In what follows, some of the most relevant features are described. These might serve as general guidelines for teachers when planning and organizing language learning activities. 


\subsection{Teaching with Total Physical Response}

Throughout the preschool years, children's maturational processes continue to develop as they gain control over their own bodies. Teachers can actively contribute to children's motor development through the use of activities based on the principle of Total Physical Response (TPR), a technique combining verbal commands, actions and gestures, first proposed by psychologist James Asher in 1969, but still popular today. Through TPR activities, for example in games like 'Simon Says' and 'Musical Statues' or well-known songs like 'Head and Shoulders' or 'The wheels on the bus', teachers encourage children to perform actions in response to verbal commands, thus maximizing their participation in classroom activity and developing their understanding of the second language, even before they are ready to talk. It is thought that TPR helps children make neurological associations between gestures and language that favours the retention of L2 input. Fine motor skills can also be improved by helping children to perfect hand and eye coordination, through pointing to pictures or flashcards, clapping musical rhythms, cutting and sticking on paper or copying simple shapes.

\subsection{Developing comprehension through simplified language use and familiar routines}

From the moment children understand the meaning of messages embedded in communicative activities, they have already begun to develop their knowledge of a second language (Krashen, 1982). In this sense, young learners are held to acquire language implicitly from multiple exposures to meaningful input rather than by engaging in conscious learning of the rules of the L2. In order to help learners make sense of L2 input, the teacher's use of non-verbal (gestures, mime) and paralinguistic (intonation, pauses; slower rate) techniques, as well as other contextual clues (object, visuals) is vital. This means that communication should be carried out directly in the L2. While young learners will not understand every word spoken by the teacher, they will often be able to grasp the general idea if they can work out the meaning of what is said from the immediate context (Kersten \& Rohde, 2013). Teachers can facilitate this process in two ways. Firstly, by adapting their language in ways similar how mothers address young children in the L1 (motherese), and by accompanying their ongoing talk with visuals, real objects and multimodal resources (e.g. the interactive whiteboard); and secondly, by engaging children in familiar and routine classroom activities. When children recognize the purpose of the activity (playing, singing, listening to a story), their role in it (listening, repeating, taking turns) and the sequence of steps or actions it involves, this knowledge acts as a cognitive support for language development (Zanón, 1992). A mental schema for each activity is created, which then frees up attentional resources allowing the children to focus on the new sounds and patterns of the second language.

\subsection{Developing lexical knowledge incidentally through recurrent exposure to} L2 words

Vocabulary acquisition is a key process in early language learning and both the amount (Bowers \& Vasilyeva, 2010) and particularly the quality of L2 input children 
are provided with (Weitz et al, 2010) has been associated to lexical development in pre-school second language learners. Children are known to engage in a three-step procedure in order to learn new words. This includes isolating word forms from the input, creating potential meanings, and mapping meanings on to forms (Rohde $\&$ Tiefenthal, 2000). While learning words in the first language is a rapid process, recent research has shown that extensive exposure to the L2 is necessary to improve children's chances of successfully retaining new words. In a study carried out with 3-to-5-year-old French-speaking EFL learners in Quebec, the children needed over 60 encounters with new L2 words, embedded in stories and songs, to reach even a $50 \%$ chance of recall (Leśniewska \& Pichette, 2016). Similar research on vocabulary acquisition with 5-year-old Spanish EFL learners (Coyle \& Gómez Gracia, 2014) provided evidence of modest gains in children's receptive word knowledge from participating in teaching sessions based on songs. This suggests that the recurrent use of stories and songs which engage children's attention are essential resources for highlighting target lexis and language patterns. Although children's word learning can occur incidentally just by listening to stories told by the teacher or from singing songs, providing definitions and explanations of key words either in the L2 (Collins, 2010) or through 'bridging' via the children's L1 (Lugo Neris, Wood Jackson \& Goldstein, 2010) during story sessions, has also been found to promote lexical acquisition and concept development in young language learners. Teachers might consider combining both techniques to enhance L2 lexical acquisition.

\subsection{Helping children to use the second language for simple communication}

Children learn to talk by talking. In young learner classrooms, children's second language output will depend on the opportunities they are given to contribute actively to the social interaction. One of the ways teachers can do this to involve the children in daily routines that require them to use the L2. By doing so children can quickly acquire a selection of memorized language chunks ('teacher finished'; 'toilet please') and prefabricated patterns ('today is.....'; 'can I....?') that will then serve as a basis for more creative language use. The use of repetition and memory drills in the form of language games will also help to drive children's initial oral production forward. Llinares (2007), for example, describes how through carefully planned activities, teachers in a low-immersion context in Spain helped 5-year-old EFL learners to express a variety of useful communicative functions in their second language. At the same time, progressively increasing children's participation in situations of scaffolded interaction through the use of drama and role play will allow them to try out their limited resources creatively. Teachers can then use a series of discursive strategies, including prompting children to repeat, to finish incomplete sentences, expanding their production and reformulating or explicitly correcting language errors. This will enable children to formulate hypotheses on the basis of input they receive, thus building up their oral competence in the second language. However, in formal instructional settings, gains in children's second language production will be understandably modest. After one year of three hourly sessions of English per week, 5-year-old Dutch children were found to have reached production levels comparable to 2-year-old children for whom English was their first language (Goorhuis-Brower \& De Bot, 2010). This is still an encou- 
raging outcome if we consider the enormous amounts of input and individualized attention that children receive in their mother tongue.

\section{Teaching the $\mathrm{L} 2$ with dramatized stories}

Storytelling is a useful resource used by parents and teachers alike to promote children's cognitive, communicative, emotional and social development. In EFL classrooms stories introduce new vocabulary and linguistic patterns in a memorable context, fostering the comprehension and promoting vocabulary acquisition and oral language development through children's active engagement with the story (Goshn, 2013). Research to date with young L2 learners in second language instructional settings has shown that stories can be effective tools for promoting children's lexical development when accompanied by explicit teaching strategies such as pointing to illustrations of key words, use of gesture and synonyms (Collins, 2010) and especially when children are actively involved in repeated storytelling sessions in which they gradually develop their ability to tell parts of the story (Chlapana \& Tafa, 2014). Data from EFL settings remains limited. However, a few available studies with EFL pre-schoolers in Spain, Quebec and Argentina have described the benefits of stories for promoting children's incidental lexical acquisition (Albaladejo, Coyle \& Roca de Larios, 2018; Leśniewska \& Pichette, 2016) and enhancing their knowledge of word order differences (adjective + noun) in the L2 (Hillyard, 2015). Their potential as a teaching resource would seem to be a worthwhile area to explore.

One of the most powerful but less well-known teaching resources for working with younger learners are dramatized stories. Dramatized story dialogues or 'formats' (Artigal, 2005) are a specific kind of oral narrative that are particularly useful in preschool and kindergarten, since they embody the theoretical and linguistic principles which are held to favour early second language acquisition. Inspired in Bruner's notion of predictable situations of scaffolded interaction, formats are short, simple stories with a clear sequence of events that can be acted out jointly between the teacher and the children. They contain key lexis and repetitive language patterns that children can anticipate, enabling them to join in quickly, thus developing comprehension and initial oral production within a shared context. As the children become more familiar with the format in successive sessions, their participation will gradually increase until they can perform the story themselves. Formats are entertaining and fun to use and children invariably enjoy the endings, which should always be surprising. The topics vary from situations which represent the children's own daily experiences (eating lunch, baking a cake, going to the doctor) to invented dialogues designed to practice specific content (the weather, food, sports). As a methodological resource, teachers can plan a sequence of activities taking the format as the starting point from which to extend initial language input through language drills, games or songs.

The dramatized narratives presented below were selected from a sample of formats written by participants in a storytelling workshop on early childhood education and adapted by the researchers to ensure they included lexis that could be easily represented with visuals and gestures as well as the repetition of key phrases to encourage oral language production. While the examples below are aimed at 5-yearold children, they can be simplified to match learners' age or language ability. The advantage of using formats is that within the chosen topics (the beach, sports, body 
parts), each story includes recurrent language patterns and lexis that are commonly found in children's everyday language, and which can, therefore, be profitably recycled on future occasions. When dramatizing the formats, the teacher's use of different voices, gestures, visuals and movement from one position to another when representing the characters, is important in helping the children to understand the scenario. In successive retellings, the children can anticipate the dialogue and join in with the teacher in saying some of the repetitive language patterns. With careful scaffolding, the children will eventually be able to recognize, act out and produce independently some of the language introduced in the narrative.

The ice cream

Tom and Lucy are at the beach.

It is summer and it's very hot.

They are eating an ice cream. Suddenly...

Tom: Oh no, I forgot my goggles! Can you hold my ice cream for a minute please?

Lucy: Yes. You need your goggles to swim in the sea.

One minute later Tom comes back. Suddenly...

Tom: Oh no, I forgot my bucket and spade! Can you hold my ice cream for a minute please?

Lucy: Yes. You need your bucket and spade to make sand castles.

Two minutes later, Tom comes back. Suddenly...

Tom: Oh no, I forgot my cap! Can you hold my ice cream for a minute please?

Lucy: Yes. You need your cap to protect your head.

Three minutes later, Tom comes back. Suddenly.....

Tom: Oh no, I forgot my towel! Can you hold my ice cream for a minute please?

Lucy: Yes. You need your towel to dry your body!

Four minutes later, Tom comes back. Then...

Tom: Can I have my ice cream please?

Lucy: Oh no!! Sorry Tom!! Your ice cream has melted!!!

Sports day

Once day it was sports day at school

Jim: I want to be the winner. I'm going to do judo

Jim fought and fought but he didn't win

Mike: Oh no! You didn't win because you're not very strong!

Jim: I want to be the winner. I'm going to swim.

Jim swam and swam but he didn't win

Mike: Oh no! You didn't win because you're not very fast!

Jim: I want to be the winner. I'm going to run a race

Jim ran and ran but he didn't win

Mike: Oh no! You didn't win because you're very slow!

Jim: I want to be the winner. I'm going to play basketball

Jim bounced and bounced the ball and he won!

Jim: Yes! I'm the winner!

Mike: Oh yes! You won because you're very tall!

But suddenly...

RINGGGGG!

Jim: Oh no! I was sleeping! 


\section{Carnival}

It was carnival time and lion, tiger, monkey and elephant and were happy.

Lion asked: What costume are you going to wear?

Tiger said: It's a secret. I can't tell you, but I have orange hair!!

Lion asked: What costume are you going to wear?

Monkey said: It's a secret. I can't tell you, but I have big blue eyes!!

Lion asked: What costume are you going to wear?

Elephant said: It's a secret. I can't tell you, but I have a red nose!!

Tiger, Monkey and Elephant asked Lion: What costume are you going to wear?

Lion said: It's a secret but I have big red lips!!

Oh no!!! Lion, tiger, monkey and elephant were wearing the same costume.

A clown!!

In what follows, some suggestions are offered on how the format 'The ice cream' might be used within a teaching sequence focused on the topic 'The beach'. In doing so, we have taken into consideration the four C's framework outlined by Coyle, Hood and Marsh (2010) in an attempt to plan lessons which can help children acquire not only new linguistic knowledge but also develop their cognitive thinking skills, intercultural awareness and affective responses to the L2 in more holistic approach to language learning. Games and songs are also included within the sequence to ensure that the learners are given the opportunity to engage in TPR and musical activities integrated within the context of the dramatized story.

Topic: The Beach

Communication

Communicative Functions Language patterns Lexis

Expressing frustration at having forgotten something (personal)

Asking for assistance (directive)

Reporting facts about the function of different objects (referential)

Apologising (interpersonal)

Reporting the result of a recent action (referential)
Oh no! I forgot my (hat)

Can you (hold my ice cream)?

You need (a cap) (to protect your head)

Sorry

Your ice cream has melted
Beach:

Ice cream; goggles; towel; cap, bucket and spade

Part of the body: head, body

Actions:

Swim; make sand castles

Time:

One, two three four minutes

\section{Content:}

Leisure activities at the beach

Packing a beach bag with useful items

Acting out a story 


\section{Cognition:}

Understand the utility of different items on the beach

Understand the relationship between cause and effect (melting)

Hypothesize about what might happen to food as a result of heat

\section{Culture:}

Identifying local holiday destinations (beaches, places of interest to visit)

\section{Session 1}

The teacher shows a picture of local places of interest to visit that the children would be familiar with (towns, buildings, countryside, beach) and asks the class who has been there.

Using a picture of a beach, the teacher asks the children what activities they can do there and what items or objects they would take to spend the day

The teacher pre-teaches key vocabulary using pictures and real objects (towel, goggles etc.) and puts them into a beach bag to contextualize the story.

The teacher asks the children what they like to eat at the beach and elicits 'ice cream'. $\mathrm{S} /$ he shows a picture of what can happen to ice cream in the sun

The teacher acts out the story using different voices, gestures, visuals and movement from one position (Lucy) to another (Tom).

The teacher asks comprehension questions (possibly in L1).

The children help the teacher to retell the story anticipating the dialogue and producing the repetitive language patterns

\section{Further Sessions}

The teacher goes on to develop the topic in subsequent sessions, in a number of ways including:

Repeated acting out of the story scaffolding the children's participation in the dialogue

Playing games using flashcards to elicit key lexis (What's in the bag?; Pass the parcel; Slow reveal; Identify the picture, Mime the action using different objects, Match actions and objects, etc.)

Singing action rhymes or songs about ice cream and parts of the body (see internet for examples) to encourage movement

Teaching or recycling beach-related food and asking children to classify it into those which will melt in the sun and those which won't (e.g. cheese, chocolate, water, sandwich, ice lolly, peach, water melon, etc.)

Teaching additional lexis and actions associated with the beach (a sun umbrella to sit in the shade; goggles to snorkel; flippers to swim), as well as some sea creatures (fish, crab, jellyfish).

Using a large template of an empty beach bag, the teacher asks children to stick pictures of the items they need for the beach onto the bag and say (with help if necessary) why they need them

The sequence of sessions should ideally conclude with the children being able to recognize and produce independently the language patterns introduced in the format. 


\section{Conclusions}

Nowadays, teaching second languages begins in kindergartens and pre-schools long before children start compulsory education. Understanding the dynamics of children's second language learning and the emergent abilities they bring to the learning situation will empower teachers to make children's initial contact with a language other than their mother tongue as fruitful as possible. A 'hands-on' approach, guided by the principles of scaffolded, dialogic interaction and participative, experiential learning, as illustrated in the use of dramatized narratives would seem to be an optimum way of supporting children's initial language learning. Repeated exposures to contextualized input in the form of a story together with successive retellings involving the gradual implication of the children as actors in the drama can help foster their comprehension and initial production of the vocabulary and language patterns contained in the story. Furthermore, when the dramatized narratives are embedded within child-friendly topics and related activities are carefully planned to include conceptual and cultural content as well as lower (e.g. remembering, understanding, etc.) and higher order thinking skills (e.g. hypothesizing, designing), they are simultaneously contributing to children's emotional, cognitive and cultural development. As a teaching resource, dramatized narratives embody a great deal of potential for early foreign language learning.

\section{Bibliographical references}

Albaladejo, Sara, Yvette Coyle \& Julio Roca de Larios (2018): "Songs, stories, and vocabulary acquisition in preschool learners of English as a foreign language", System, 76, 116-128.

Artigal, Josep María (2003): "Ready for a story! Materiales para la enseñanza del ingles como L3 en contextos mulitilingües", Revista de Psicodidáctica, 16. http://www.redalyc. org/articulo.oa? id $=17501610$ [Consulted: $16^{\text {th }}$ September 2017]

Artigal, Josep María (2005): El texto narrativo dialogado. Una manera de construir el aprendizaje de la lengua extranjera en educación infantil, Barcelona, Centre de Recursos de Llengües Estrangeres. Departament d'Educació. Generalitat de Catalunya. http://www. xtec.es/crle/02/infantil/index.htm [Consulted: $16^{\text {th }}$ September 2017]

Asher, James (1969): "The Total Physical Response Approach to Second Language Learning", The Modern Language Journal, 53.1, 3-17.

Bowers, Edmond, \& Marina Vasilyeva (2011): "The relation between teacher input and lexical growth of pre-schoolers", Applied Psycholinguistics, 32.1, 221-241. doi:10.1017/ S0142716410000354

Bruner, Jerome (1985): Child's talk: Learning to use language; New York, Norton.

Cameron, Lynn (2003): "Challenges for ELT from the expansion in teaching children", ELT Journal, 57.2, 105-112. doi: https://doi.org/10.1093/elt/57.2.105

Chlapana, Elissavet \& Tata, Eufimia (2014): "Effective practices to enhance immigrant kindergarteners' second language vocabulary learning through storybook reading", Reading and Writing, 27.9, 1619-1640. doi:https://doi.org/10.1007/s11145-014-9510-7

Collins, Molly (2010): "ELL preschoolers' English vocabulary acquisition from storybook reading", Early Childhood Research Quarterly, 25.1, 84-97. doi: https://doi.org/10.1016/j.ecresq.2009.07.009 
Coyle, Do, Philip Hood \& David Marsh (2010): Content and Language Integrated Learning, Cambridge, Cambridge University Press.

Coyle, Yvette, \& Remei Gómez Gracia (2014): "Using songs to enhance L2 vocabulary acquisition in preschool children”, ELT Journal, 68.3, 276-285. doi:https:/doi.org/ 1093/ elt/ccu015.

Curtain, Helena (2003): "Early language learning in the USA", in M. Nikolov \& H. Curtain (eds.), An early start: Young learners and modern languages in Europe and beyond, Strasbourg, Council of Europe, 191-208.

Goorhuis-Brouwer, Sineke, \& Kees de Bot (2010): "Impact of early English language teachuing on L1 and L2 development in children in Dutch schools", International Journal of Bilingualism, 14.3, 289-302. doi:https://doi.org/10.1177/1367006910367846

Goshn, Irma (2013): "Humanizing teaching English to young learners with children's literature", CLELE Journal, 1.1, 39-57. http://clelejournal.org/humanizing_teaching-english to_young_learners_with_childrens_literature/[Consulted: $15^{\text {th }}$ August 2018]

Hillyard, Sara (2015): "Rythmic patterns in stories and word order production (adjective +) in four-year-old EFL learners", in Victoria Murphy \& María Evangelou (eds), Early Childhood Education in English for Speakers of Other Languages, London, British Council, 279-292

Kersten, Krisitn, \& Andreas Rohde (2013): “Teaching English to young learners", in A. Flyman Mattson \& C. Norrby (eds.), Language Acquisition and Use in Mulitlingual Contexts. Theory and Practice, Lund, Lund University, 107-121

Krashen, Stephen (1982): Principles and practice in second language acquisition, Oxford, Pergamon.

Lenneberg, Eric, Noam Chomsky \& Otto Marx (1967): Biological foundations of language, New York, Wiley.

Leśniewska, Justyna, \& François Pichette (2016): "Songs vs. Stories: Impact of input sources on ESL vocabulary acquisition by preliterate children", International Journal of Bilingual Education and Bilingualism, 19.1, 18-34. doi:https://doi: 10.1080/13670050.2014.960360

Llinares García, Ana (2007): "Young learners' functional use of the L2 in a low-immersion EFL context”, ELT Journal, 61.1, 39-45. doi:https://doi.org/10.1093/elt/ccl043

Lugo-Neris, Mirza, Carla Wood Jackson \& Howard Goldstein (2010): "Facilitating Vocabulary Acquisition of Young English Language Learners", Language, Speech, and Hearing Services in Schools, 41, 314-327. doi:10.1044/0161-1461(2009/07-0082)

Marinova-Todd, Stefka, Bradford Marshall \& Catherine Snow (2000): "Three misconceptions about age and L2 learning", TESOL Quarterly, 34.1, 9-34. doi:http://doi: $10.2307 / 3588095$

Muñoz, Carmen (ed.) (2006): Age and the Rate of Foreign Language Learning, Clevedon. Multilingual Matters.

Rixon, Shelagh (2013): British Council Survey of Policy and Practice in primary English Language Teaching Worldwide, London, British Council.

Rohde, Andreas, \& Christine Tiefenthal (2000): "Fast Mapping in Early L2 Lexical Acquisition", Studia Linguistica, 54.2, 167-174. doi:http://doi:10.1111/1467-9582.00057

Unsworth, Sharon, Liv Persson, Tineke Prins \& Kees de Bot (2015): “An investigation into the factors affecting early foreign language learning in the Netherlands", Applied Linguistics, 36.5, 527-548. doi:https://doi.org/10.1093/applin/amt052

Weitz, Martina, Svenja Pahl, Ana Flyman Mattsson, Aafl Buyl \& Elke Kalbe (2010): “The Input Quality Observation Scheme (IQOS): The nature of L2 input and its influence on L2 development in bilingual preschools", in K. Kersten, A. Rohde, C. Schelletter \& A. 
K. Steinlein (eds.), Bilingual Preschools (Vol. 1. Learning and Development), Trier, Wissenschaftlicher Verlag, 45-68.

Zanón, Javier (1992): “Cómo no impedir que los niños aprendan inglés", Comunicación, Lenguaje y Educación, 16, 93-110. doi:http://dx.doi.org/10.1080/02147033.1992.10821 052 